\title{
SIKAP APARATUR SIPIL NEGARA TENTANG KEBIJAKAN PENSIUN DINI DAN DAMPAK PSIKOLOGISNYA \\ (Studi Komparasi di PTU dan PTKI Sumbar)
}

\author{
Reza Fahmi \\ Syafruddin Nurdin \\ Asnawir \\ Tri Amanda \\ (IAIN Imam Bonjol Padang. Email: rezafahmi125@gmail.com, asnawir47@yahoo.com, \\ syafruddinnurdin@yahoo.com, triamanda@gmail.com)
}

\begin{abstract}
Penelitian ini berangkat dari fakta tentang kebijakan pemerintah yang akan diberlakukan pada akbir tahun 2016 atau awal tahun 2017. Di mana pemerintah akan mempesiundinikan Aparatur Sipil Negara (ASN) I Pegawai Negeri Sipil (PNS) secara nasional. Adapun ASN/PNS yang akan dipensiun dinikan adalah ASN/ PNS yang berpendidikan SMA kebawah. Lebih jauh penelitian ini akan mengkaji "Sikap Aparatur Sipil Negara Tentang Kebijakan Pensiun Dini dan Dampak Psikologisnya". Penelitian ini menggunakan pendekatan kuantitatif. Populasi penelitian sebanyak 534 orang. Sedangkan sampel dalam penelitian sebanyak 189 orang. Teknik pengumpulan data yang digunakan adalah skala psikologi, wawancara dan studi dokumentasi. Teknik penarikan sampel yang digunakan adalah simple random sampling (penarikan sampel acak sederhana), ini dilakukan mengingat sampel memiliki kearngka sampel yang jelas. Teknik analisa data menggunakan alat bantu SPSS (Statistical package for Social Science) dengan model statistik pearson correlation, regresi sederhana dan Anova. Hasil penelitian mendapati: (1) Ada hubungan antara sikap penerimaan ASN/PNS dan dampak psikologisnya. (2) Adanya pengaruh yang besar, yakni sebanyak enampuluh delapan persen (68\%) dari sikap penerimaan ASNIPNS terhadap spsikologisnya. (3) Adanya perbedaan tingkat depresi, kecemasan dan stres dikalangan ASN/PNS dilingkungan Perguruan Tinggi Umum (Universitas Andalas dan Universitas Negeri Padang) dan Perguruan Tinggi Ke-Islaman (PTKI). Di mana tingkat depresi, kecemasan dan stres lebih tinggi dikalngan ASN/PNS di PTKI berbanding PTU.
\end{abstract}

Kata Kunci: Aparatur Sipil Negara, Depresi, Kecemasan dan Stres.

\section{PENDAHULUAN}

Pegawai negeri sipil (PNS) tampaknya tidak pernah lepas dari sorotan masyarakat. Kondisi itu bisa dimengerti, karena baik secara personal maupun institusional, PNS merupakan organ negara yang diberi tugas menjalankan semua kebijakan pemerintah yang terkait dengan kepentingan masyarakat. Peran ini menjadi strategis karena hanya mereka yang memiliki wewenang (legitimasi) serta akses atas kepentingan publik. Tidak bisa dimungkiri sepanjang hidup kita, dari lahir, dewasa, menikah, hingga meninggal, akan selalu berhubungan dengan pegawai negeri. PNS juga sebagai unsur utama sumber daya yang berperan mengemban tugastugas pemerintahan dan pembangunan.

Selanjutnya pensiun merupakan tahapan akhir perkembangan yang akan dialami oleh setiap orang yang bekerja dimana pada masa tersebut seseorang akan mengalami perobahaan peran maupun pola hidup dari kondisi bekerja menjadi kondisi tidak bekerja yang akan 
membawa dampak bagi pensiunan itu sendiri dan keluarganya Para aparatur Sipil Negara (ASN) atau Pegawai Negeri Sipil (PNS) harus siap-siap menghadapi pensiun dini. Kebijakan ini diberlakukan bagi pegawai yang kompetensinya rendah dan tidak bisa dikembangkan lagi. "Dalam rangka penataan struktur organisasi kepegawaian, pemerintah akan mengambil kebijakan pensiun dini. Pensiun dini akan dikenakan secara nasional mulai tahun 2016, kepada pegawai yang kualitasnya rendah," tegas Deputi SDM Aparatur Kementerian Pendayagunaan Aparatur Negara dan Reformasi Birokrasi (KemenPANRB) Setiawan Wangsaatmaja, Minggu (16/11) (http://www.jpnn.com)

Dengan alasan tuntutan global (Fakta berikut akan memberikan gambaran bahwa telah terjadi perubahan trend proses pensiun dikalangan perka di Uni Eropa seiring perlambatan ekonomi di beberapa negara benua biru tersebut yang berdampak pada peningkatan jumlah pekerja yang lebih memilih atau dipaksa untuk mengalami pensiun dini. . "...Demographic data about the European Union countries show a high increase in the percentage of elderly people. Population aging endangers the sustainability of pension systems, and for this reason in 2001 the European Council made a proposal for half the population aged between 55 and 64 years old to be employed in 2010, and among other measures it also proposed that retirement age should be increased. These objectives were not met; in fact, it was not until 2008 with the growing economic crisis that EU countries began to raise the retirement age as occurred in Spain in 2010, where retirement is at 67. However, raising the retirement age has not increased the percentage of the older workforce, but completely the opposite The reasons that explain this situation are diverse and interconnected. On the one hand, from the short term socioeconomic view, the productive system prefers a younger age and lower cost structure of the workforce; and on the other hand, there is a social perception of the significance of aging as a decreasing in skills. All this means that potential human resources, which correspond to the older more experienced workers, are no longer being taken advantage of For the above reasons, raising the retirement age is seen as something negative by many workers and in the older population there is still a tendency to withdraw from the labor market. In the last decade a lot of research has been carried out to analyze the psychosocial causes of the individual intention of workers to take early retirement. In a sample of Finnish workers, it was found that 55\% of women and 52\% of men had intentions of retiring early. Another studied the responses of a wide sample of employees from 10 different countries: Germany, Austria, Denmark, France, Greece, Holland, Italy, Sweden and Switzerland, and found that $48 \%$ of the employees studied express the intention to retire as early as possible - Holland being the country with the lowest intention to retire early (29.7\%), and Spain being the country with the highest prevalence in the intention to retire early (67.2\%). Naturally, there is a great variation between professions, for example in a study with nurses, it was found that $72 \%$ had the intention of retiring early". (Jordi Fernández-Castro et al. 2015)", serta pengurangan belanja pegawai, pemerintah berencana melakukan rasionalisasi (pensiun dini) pegawai sejuta orang ditambah 560 ribu PNS yang masuk batas usia pensiun. Pemerintahan Jokowi-JK menargetkan, jumlah PNS di Indonesia pada 2019 mendatang menciut ke angka 3,5 juta dari 4,517 juta PNS yang ada. Argumentasi di atas didukung oleh pernyataan

\section{4 || Turãst: Jurnal Penelitian \& Pengabdian Vol. 4, No. 2, Juli - Desember 2016}


Ketua Komisi II DPR Rambe Kamarulzaman menyatakan mendukung kebijakan MenPANRB Yuddy Chrisnandi yang akan menerapkan rasionalisasi alias pemangkasan jumlah PNS . Namun upaya pensiun dini itu harus diawali dengan road map yang jelas. Mulai dari data data jumlah PNS dan kompetensinya. Termasuk juga data mengenai kinerja tenaga honorer atau sukarelawan. "Kalau ada road map, datanya jelas, silakan saja PNS yang kompetensinya rendah cepat saja dipensiunkan (pensiun dini, red)," terang Rambe Kamarulzaman .

Paradoksial persoalan pensiun dini digambarkan oleh Bernhard Ebbinghaus dalam bukunya "Reforming Early Retirement in Europe, Japan and the USA" menyatakan (Bernhard Ebbinghaus, 2006):

\begin{abstract}
“...Today, people live longer, yet they also tend to retire earlier. This paradox concerns not only the student of modern societies but also current political debates around the world. Since the 1970s, older working people have been withdrawing from employment prior to statutory pension age (commonly around age 65) at increasingly higher rates across all advanced industrialized economies, including the member states of the European Union, Japan, and the United States.."
\end{abstract}

Paradoks bermula ketika orang hidup semakin lama, seiring peningkatan kesejahateraan yang dialami oleh negara industri. Sedangkan para pekerja menginginkan untuk pensiun dini. Terdapat dua alasan utama pekerja ingin melakukan pensiun dini : (1) sebagai suatu konsekwensi yang tidak diharapkan dari perluasan hak sosial. (2) Sebagai kebijakan yang disengaja untuk memfasilitasi restrukturisasi ekonomi dan mengurangi jumlah pengangguran. Sehingga pensiun dini tidak hanya merupakan politik pertentangan terhadap pasar.
Sungguhpun demikian fakta implementasi pensiun dini telah dijalankan oleh pemerintah propinsi Jawa Barat di mana “..Kamis tanggal 5 Agustus 2010 merupakan tonggak baru bagi Pemerintah Provinsi Jawa Barat. Hari itu Pemprov Jabar mulai menerapkan kebijakan rasionalisasi pegawai negeri sipil (PNS) melalui program pensiun dini”. Sebanyak 53 PNS Pemprov Jabar menerima Surat Keputusan (SK) Gubernur Jabar tentang rasionalisasi sekaligus uang kompensasinya. kebijakan ini ditetapkan dengan Peraturan Gubernur (Pergub) Jabar No 81 Tahun 2009 yang diundangkan pada 2 Juli 2009, yang selanjutnya diubah menjadi Pergub Jabar No 100/2009 dengan menyisipkan Bab VA di antara Bab V dan Bab VI, yang menyebutkan pembiayaan program pensiun dini dibebankan pada Anggaran Pendapatan dan Belanja Daerah (APBD) Provinsi Jabar. Berangkat dari latar belakang di atas diperoleh gambaran bahwa, telah dimplementasikannya Peraturan Pensiun Dini bagi Aparatur Sipil Negara (ASN/PNS) di beberapa daerah di tanah air, sejak tahun 2010 . Selanjutnya Peraturan Pensiun Dini tersebut akan diterapkan secara nasional mulai pada tahun 2016. Hanya saja Aparatur Sipil Negara yang akan dipensiunkan dini baru sebatas pada pegawai yang memiliki pendidikan Sekolah Menangah Atas ke bawah. Apakah fakta di atas membawa polemik psikologis ditengah-tengah masyarakat?

Secara spesifik pertanyaan penelitian ini adalah : Apakah Sikap Aparatur Sipil Negara dalam Menghadapi Program Pensiun Dini yang Diterapkan Sebagai Kebijakan Nasional Memberi Dampak Psikologis pada para Aparatur Sipil Negara (Dampak psikologis berupa; Depresi, Kecemasan atau Anxiety dan Stres)? Adapun 
signifikansi penelitian ini adalah: (1) Memperoleh gambaran tentang sikap (kognitif, afektif dan psikomotorik) Aparatur Sipil Negara terhadap kebijakan pemerintah mengenai Program Pensiun Dini. (2) Mengidentifikasi kemungkinan munculnya berbagai ganguan psikologis (depresi, kecemasan atau stres) yang akan terjadi sebagai dampak psikologis dari kebijakan pensiun dini yang dilaksanakan pemerintah kepada para Aparatur Sipil Negara. (3) Mengkaji pengaruh sikap Aparatur Sipil Negara tentang pensiun dini terhadap ganguan psikologis yang dialaminya (4) Mengkaji perbedaan sikap Aparatur Sipil Negara tentang pensiun dini dan dampak psikologisnya.

\section{METODOLOGI}

Model rancangan yang digunakan dalam penelitian ini adalah deskriptif kuantitatif.Adapun yang dimaksudkan dengan metode kuantitatif disini adalah metode yang bersifat realitas (dapat diklasifikasikan, komkrit, teramati dan terukur). Kemudian dari aspek hubungan antara peneliti dan objek penelitian bersifat independen (bebas) supaya terbangun objektivitas. Secara lebih khusus penelitian ini akan mengkaji : (1) Hubungan antara sikap Aparatur Sipil Negara dalam menghadapi Program Pendiun Dini dan dampak psikologis yang dialaminya (depresi, kecemasan dan stres). (2) Melihat pengaruh sikap Aparatur Sipil Negara dalam menghadapi Program Pendiun Dini terhadap kondisi psikologis ASN (depresi, kecemasan dan stres). (3) Menemukan perbedaan sikap Aparatur Sipil Negara dalam menghadapi Program Pendiun Dini dan dampak psikologis yang dialaminya (depresi, kecemasan dan stres) antara Aparatur Sipil Negara yang bekerja di
Perguruan Tinggi Umum (PTU); Universitas Andalas dan Universitas Negeri Padang serta Perguruan Tinggi Ke-Islaman (PTKI); IAIN Imam Bonjol Padang dan IAIN Djamil Djambek Bukittinggi.

Lokasi peneliian ini meliputi empat perguruan tinggi negeri yang ada di Sumatera Barat : (1) Institut Agama Islam Negeri Imam Bonjol Padang (IAIN-IB). (2) Universitas Negeri Padang (UNP). (3) Universitas Andalas Padang (UA) dan Institut Agama Islam Negeri Djamil Djambek Bukittinggi. Pemilihan ke empat perguruan tinggi negeri tersebut lebih didasari pada hal-hal sebagai berikut : (1) Keberadaan Aparatur Sipil Negara (ASN/PNS) pada keempat perguruan tinggi negeri tersebut diasumsikan mampu mewakili gambaran dari keberadaan Aparatur Sipil Negara lain di Sumatera Barat, khususnya yang bergerak dibidang pendidikan atau pelayanan jasa publik. (2) Karakteristik dari Aparatur Sipil Negara (ASN/PNS) pada keempat Perguruan Tinggi Negeri tersebut memiliki kecenderungan homogen atau memiliki tingkat homogentitas yang tinggi dengan Pegawai Negeri Sipil lain dilingkungan Kementerian Agama RI dan Kementerian Riset dan Pendidikan Tinggi RI. (3) Mengikut teori yang telah dijelaskan pada bab terdahulu (Bab II), berbagai persoalan psikologis sehubungan pensiun dini umumnya berkaitan dengan depresi, kecemasan dan stres. Sehingga pemilihan penggunaan alat ukur atau skala DASS (Depression, Anxiety dan Stress Scale) yang diasumsikan sesuai bagi mengkaji masalah psikologis yang dialami oleh Aparatur Sipil Negera (ASN/PNS) di pelbagai perguruan tinggi negeri tersebut. Selanjutnya populasi dalam penelitian adalah seluruh Aparatur Sipil Negera (ASN/PNS) 
yang potensi untuk dipensiun dinikan (memiliki tingkat pendidikan akhir Sekolah Menengah Atas ke bawah), adapun jumlah mereka sebanyak 534 orang. Sungguh demikian sampel dalam penelitian ini adalah sebanyak 189 orang atau setara dengan tiga puluh lima koma tiga puluh sembilan persen $(35,39 \%)$.

Adapun teknik penarikan sampel yang digunakan melalui dua tahap antara lain : (1) Stratified random sampling. Pemlihan responden dengan menggunakan metode stratified random sampiling, mengingat sampel dalam penelitian ini memiliki kerangka sampel yang berjenjang (Gol I, Gol II, dan Gol III). (2) Metode pengambilan sampel acak sederhana (simple random sampling) yang dipilih dengan mengundi unsure-unsur penelitian atau satuan-satuan elementer dalam populasi. Hal sedemikian dipilih mengingat unit elementer (unit penelitian) telah tersusun dalam kerangka sampling (sampling frame) berupa daftar pegawai pada masing-masing fakultas atau institut atau kantor pusat di universitas. Terdapat tiga bentuk teknik pengumpulan data dalam penelitian ini, antara lain: (1) Angket atau keusioner. (2) Skala Psikologi. (3) Dokumentasi.

\section{PEMBAHASAN}

Pada Bab ini akan dijelaskan beberapa hasil penelitian dan pembahasan terhadap penelitian yang dijalankan. Adapun rincian lengkap hasil penelitian ini antara lain sebagai berikut:

\section{Hasil Analisa Deskriptif}

Berdasarkan penyebaran min (rerata), diperoleh gambaran bahwa sikap ASN/PNS penerimaan tentang pensiun dini tergolong pada kategori rendah. Di mana Sebesar 72 orang setara dengan jumlah tiga puluh delapan persen koma nol sembilan persen $(38,09 \%)$ berada pada kategori tinggi. Sedangkan penerimaan PNS/ASN tentang pensiun dini yang tergolong tinggi sebanyak 117 orang atau setara dengan enampuluh satu koma sembilan puluh satu persen $(61,91 \%)$. Ini bermakna bahwa umumnya responden menolak pemerintah untuk menerapkan kebijakan pensiun dini terhadap para ASN/PNS. Keadaan ini diduga karena para ASN atau PNS mereka tidak memperoleh informasi dan pengetahuan mengetahui atau memperoleh gambaran tentang masa depan mereka dikemudian hari. Di mana mereka khawatir kalau mereka harus mencari pekerjaan baru maka, tidak ada perusahaan yang akan menerima. Kemudian kalaulah para ASN atau PNS akan mengembangkan bisnis atau usaha maka, jenis bisnis atau usaha apa yang harus mereka kerjakan apabila mereka sudah pensiun nantinya.

\section{Hasil Analisa Kuantitatif, Hasil Pengujian Korelasi}

Berdasarkan analisa data diperoleh gambaran bahwa pada pengujian korelasi pearson (product momment) didapati $r$ hitung adalah -0,639 (untuk analisa hubungan antara sikap ASN/ PNS menghadapi pensiun dini dengan kondisi psikologisnya (DAS atau Depression/Depresi, Anxiety/Kecemasan and Stress/Stres). Sedangkan nilai $r$ tabel pada peubah tersebut adalah 0,138 Sehingga $r$ hitung $>r$ tabel, $\mathrm{Ho}=$ Ditolak dan $\mathrm{H} 1$ = Diterima, pada penujian hubungan antara sikap penerimaan ASN/PNS dalam menghadapi pensiun dini dan dampak psikologisnya (Depression/Depresi, Anxiety/Kecemasan dan Stress/Stres). Artinya ada hubungan yang bersifat negatif antara kedua peubah atau variabel (sikap 
penerimaan dengan dampak psikologisnya). Sungguhpun demikian korelasi bersifat negatif artinya sikap penerimaan ASN/PNS yang rendah tadi (berdasarkan hasil telaah penyebaran rerata atau mean yang telah dijelaskan terdahulu) maka, ianya meningkatkan dampak psikologisnya. Dengan kata lain, semakin lemah penolakan yang dilakukan oleh para PNS/ASN dalam kebijakan pensiun dini maka, akan meningkatkan dampak psikologis yang dihadapi (depresi, kecemasan dan stres) oleh para ASN/PNS.

\section{Hasil Pengujian Pengaruh}

Secara keseluruhan menunjukkan Angka $\mathrm{R}$ square $=0,678$ (adalah pengkuadranan dari koefisien korelasi antara $0,824 \times 0,824=0,678)$. $R$ square dapat disebut sebagai koefisien determinan yang dalam hal ini berarti : hanya terdapat $68 \%$ pengaruh sikap ASN/PNS terhadap dampak psikologisnya, Kecemasan dan Stres (Depression, Anxiety and Stress). Sedangkan sisanya (100\% $68 \%=42 \%$ ) disebabkan oleh faktor lain. Hal ini membuktikan bahwa sikap penerimaan ASN/ PNS tentang kebijakan pensiun dini memebrikan pengaruh yang besar atau berarti terhadap dampak psikologisnya. Sungguhpun demikian masih ada faktor lain yang berperan, antara lain seperti; dukungan sosial lingkungan keluarga, usia, pendidikan, jenis kelamin dan sebagainya.

\section{Hasil Pengujian Perbedaan Sikap ASN/PNS yang Bekerja di PTKI atau PTU}

Selanjutnya berdasarkan hasil kajian ini didapati dengan Uji Anova Satu Jalur diperoleh F hitung $=4,16$ dan Ftabel = 3,072. Karena Fhitung $>$ Ftabel, dapat disimpulkan bahwa terdapat perbedaan sikap ASN/PNS tentang kebijakan pensiun dini dan dampak psikologisnya: antara
ASN/PNS yang bekerja di Perguruan Tinggi KeIslaman dan Perguruan Tinggi Umum.

Berikutnya penelitian yang dilakukan oleh Candra Dewi Kusumarini (2007) tentang "Pengaruh Sikap Menghadapi Pensiun Terhadap Penyesuaian Diri Menjelang Masa Pensiun (Penelitian Pada Pegawai Negeri Sipil Yang Memiliki Jabatan Eselon IV-II di Kabupaten Tegal Tahun 2006)" mendapati hasil analisis data dengan menggunakan program SPSS 18 didapatkan angka $\mathrm{F}$ sebesar 52,667 dengan harga $p$ sebesar 0,000 skor ini lebih kecil dari taraf signifikansi yang digunakan yaitu $0,05(0,000<0,05)$ dengan demikian hasil analisis ini menunjukkan bahwa ada pengaruh sikap menghadapi pensiun terhadap penyesuaian diri menjelang masa pensiun pada PNS yang memiliki jabatan eselon IV-II di Kantor Pemerintah Daerah Kabupaten Tegal Tahun 2006. Hasil penelitian di atas tidak didukung oleh penelitian yang tim peneliti ini lakukan, mengingat penelitian terdahulu diatas mendapati adanya pengaruh yang positif dalam sikap menghadapi pensiun. Manakala penelitian yang dijalankan oleh tim peneliti mendapati adanya sikap negatif (rendahnya) sikap penerimaan ASN/PNS terhadap pensiun dini. Ini bermakna bahwa para ASN/ PNS memandang negatif terhadap masa pensiun dini. Dengan kata lain dapat disimpulkan bahwa penelitian terdahulu di atas tidak didukung oleh penelitian yang dilakukan oleh tim peneliti ini.

Penelitian oleh Gantina Komalasari (2013) tentang Kecemasan menghadapi pensiun: studi mengenai hubungan antara makna hidup, dukungan sosial, dan sikap dengan kecemasan menghadapi pensiun pada Pegawai Negeri Sipil di DKI Jakarta Di mana penelitian ini mendapati 
bahwa: (1) Hasil analisis Korelasi Sederhana Product Moment dan analisis regresi berganda terhadap variabel yang diteliti menunjukkan Makna Hidup, Dukungan Sosial dan Sikap terhadap pensiun secara keseluruhan memiliki hubungan negatif yang signifikan dengan Kecemasan menghadapi pensiun. Dengan perkataan lain semakin Bermakna Hidup PNS yang MPP, semakin tinggi Dukungan Sosial dan semakin positif Sikap terhadap pensiun, maka akan semakin rendah Kecemasan menghadapi pensiun. Akan tetapi berdasarkan analisis lanjutan Korelasi Parsial terbukti Dukungan Sosial tidak memiliki hubungan yang signifikan dengan Kecemasan menghadapi pensiun. Dengan demikian dapat diartikan bahwa tinggi rendahnya tingkat kecemasan menghadapi pensiun pada PNS yang MPP hanya dipengaruhi tinggi rendahnya makna hidup yang dimiliki dan positif tidaknya sikap mereka terhadap pensiun. (2) Berdasarkan hasil analisis deskriptif, menunjukkan PNS yang MPP pada umumnya memiliki Makna Hidup yang tinggi, Dukungan Sosial yang tinggi, Sikap yang positif terhadap pensiun dan Kecemasan yang rendah dalam menghadapi pensiun. Penelitian di atas memperoleh dukungan oleh penelitian yang dijalankan oleh tim peneliti ini, di mana penelitian oleh tim peneliti mendapati adanya kecenderungan persoalan psikologis (kecemasan) yang dialami oleh para ASN/PNS yang akan mengalami masa pensiun.

\section{Rekomendasi}

Terdapat beberapa catatan yang merupakan saran dalam persiapan pensiun dini yang perlu dilakukan adalah sebagai berikut: (1) Persiapan pensiun hendaknya tidak hanya mempersiapkan aspek finansial atau ekonomi saja, tetapi juga aspek psikologis, fisik-kesehatan dan sosial peserta. (2) Program persiapan pensiun hendaknya tidak hanya memberikan pengetahuan saja tetapi sampai melatihkan ketrampilan yang harus dimiliki pada setiap aspek persiapan pensiun. (3) Perlu diperhatikan penentuan peserta karena perlu mempertimbangkan lamanya waktu pensiun tiba, misalnya persiapan 10 tahun lagi pensiun tentunya akan berbeda dengan 5 tahun atau 1 tahun lagi pensiun. Perlu dipertimbangkan pula karakteristik pekerjaan, misalnya persiapan pensiun antara karyawan edukatif akan berbeda dengan persiapan pesiun karyawan non-edukatif. Peserta pelatihan persiapan pensiun sebaiknya diikuti oleh pasangan suami istri. (4) Bagi keluarga pegawai negeri sipil / aparatur sipil negara (PNS/ASN) yang hendak menghadapi masa pensiun, hendaknya dapat meningkatkan dukungan kepada keluarga yang akan menghadapi masa pensiun, karena keluarga merupakan kunci utama atau lingkungan pertama yang dapat memberi semangat atau dukungan sosial seorang bapak atau suami untuk bertahan menjalani kehidupan. (5) Bagi instansi pemerintah tempat ASN/PNS bekerja, hendaknya melakukan masa pensiun dini sejak lebih awal, sehingga pada diri pegawai yang akan menghadapi masa pensiun tidak akan kaget ketika menghadapi masa tersebut. (6) Bagi teman-teman yang berada pada lingkungan kerja yang sama hendaknya saling memberi motivasi pada teman yang hendak menghadapi masa pensiun, sehingga diharapkan pada diri pegawai tersebut akan memiliki konsep diri dan selalu berfikir positif setelah memperoleh dukungan dari teman-teman sekitarnya.

Apabila peneliti lain mengkaji lebih lanjut tentang ganguan psikologis yang dialami oleh ASN/PNS maka, berbagai terapi mungkin 
dijadikan pilihan untuk mengatasi masalah depresi, kecemasan dan stres diantaranya: (1) Terapi psikofarmaka adalah pengobatan untuk stres, cemas, dan atau depresi dengan obat-obatan (farmaka) yang mampu memulihkan fungsi gangguan neurotransmitter (sinyal penghantar saraf) disusunan saraf pusat otak (lymbik system). (2) Terapi Somatik. Seseorang yang menderita stres, cemas ataupun depresi dapat mempengaruhi ketahanan dan kekebalan fisiknya berupa gejala dan keluhan fisik (somatik) sebagai gejala ikutan atau akibat dari stres, kecemasan dan depresi yang berkepanjangan seperti keluhan-keluhan pada sistem pencernaan, kardiovaskuler, pernapasan, urogenetal, otot dan tulang dan lain sebagainya.

\section{DAFTAR PUSTAKA}

Baron, R.A., \& Byrne, D. (2000). Social psychology, $9^{\text {th }}$ ed. Boston: Allyn\& Bacon.

Boumans, N.P.G., de Jong, A.H.J. and Vanderlinden, L. (2008). Determinants of Early Retirement Intentions among Belgian Nurses. Journal of Advanced Nursing, 63.

Eko Budiono: Menghitung Jumlah PNS yang Proporsional, Suara Merdeka, 7 Juli 2011.

Elia. (2015). Post Power Syndrome.http://www. sabda.org/ Diakses 10 April 2016

Elovainio, M., Kivimaki, M., Vahtera, J., Ojanlatva, A., Korkeila, K., Suominen, S., Helenius, H. and Koskenvuo, M. (2003). Social Support, Early Retirement, and a Retirement Preference: A Study of 10,489 Finnish Adults. Journal of Occupational and Environmental Medicine, 45.
Gendron, B. (2011). Older Workers and Active Ageing in France: The Changing Early Retirement and Company Approach. The International Journal of Human Resource Management, 22.

Helmi, A. F. (2011). Pengelolaan Stress PraPurn Bakti. Psikologika: No. 9 (42-55). Yogyakarta:Universitas Gadjah Mada.

Jordi Fernández-Castro. Dkk. (2015). Early Retirement Intention in Workers from the Industry and Service Sectors: Influence of the Perception of Benefits from Retiring or from Continuing to Work. Open Journal of Social Sciences, 2015, 3.

Kuncoro,J.,Sari,E.D. (2012). Kecemasan dalam Menghadapi Masa Pensiun Ditinjau dari Dukungan Sosialpada PT.Semen Gresik(Persero) Tbk. Jurnal Psikologi Proyeksi. Vol.1, No. 1.

Morshhäuser, M. and Sochert, R. (2006). Health Work in an Ageing Europe. Fedearal Association of Company Health Insurance Funds, Esse.

Rini, J. F. (2011). Pensiun Dan Pengaruhnya. http://www.e-psikologi.com Diakses 10 April 2016.

Siegrist, J., Wahrendorf, M., von dem Knesebeck, O., Jürges, H. and Börsch-Supan, A. (2007). Quality of Work, Well-Being, and Intended Early Retirement of Older Employees: Baseline Results from the SHARE Study. The European Journal of Public Health, 17. Sofia,K. (2011). Pengaruh Konsep Diri Terhadap Tingkat Kecemasan Menghadapi Masa Pensiun Pada Pegawai Negri Sipil Dinas 
Perindustrian, Perdagangan, danPenanaman

Modal KabupatenSumenep. Skripsi. Malang:

Fakultas Psikologi Unviersitas Islam Negri

(UIN) Malang. www.uin-malang.ac.id.

Diakses 14 April 2016.

Staubli, S. and Zweimüller, J. (2013). Does

Raising the Early Retirement Age Increase

Employment of Older Workers? Journal of

Public Economics, 108.

\section{Internet}

http://www.pusatinfocpns.com

http://wikipns.com

http://informasibumncpns.com

https://dytautami.wordpress.com

http://www.jpnn.com

http://economy.okezone.com

Elia.2015.Post Power Syndrome.http://www.sabda. org/ Diakses 10 April 2016

\section{Media Massa dan Media Cetak}

Detik Finance, Selasa, 21 Juni 2011: Keuangan Negara 'Menyempit' Karena Jumlah PNS 'Membengkak'.

Editoriaal Media Indonesia, Rabu, 29 Juni 2011:

Diet untuk Birokrasi

Kompas, 18 Juli 2011: Negara Bertaburan Lembaga

Kompas, 21 September 2010: Rusia Pangkas 100.000 Pegawai Negeri

Suara Pembaharuan, 6 Juni 2012.

\section{Peraturan-Peraturan}

UU No 11 tahun 1969 tentang Pensiun Pegawai dan Pensiun Janda/Duda Pegawai. 
